\title{
THE POSSIBLE BENEFICAL EFFECT OF AMPELOPSIN ON INJURIES OF OVARIAN AND LUNG TISSUES GENERATEDBY OVARIAN TORSION/DETORSION
}

\author{
E. P. Topdağı Yılmaz ${ }^{1}$, A. Tanyeli², F. N. Ekinci Akdemir ${ }^{3 *}$, M. C. Güler ${ }^{2}$ and E. Eraslan ${ }^{4}$ \\ ${ }^{1}$ Department of Gynecology and Obstetrics, Faculty of Medicine, Atatürk University, Erzurum, Turkey. \\ ${ }^{2}$ Department of Physiology, Faculty of Medicine, Atatürk University, Erzurum, Turkey. \\ ${ }^{3}$ Department of Nutrition and Dietetics, High School of Health, Ağrı İbrahim Çeçen University, Ağrı, Turkey. \\ ${ }^{4}$ Department of Physiology, Faculty of Medicine, Bozok University, Yozgat, Turkey. \\ "Corresponding Author's E-mail: fazilenur@yandex.com
}

\begin{abstract}
The aim of this study was to investigate the effects of ampelopsin (AMP) on injuries of ovarian and lung tissues generated by bilateral ovarian torsion/detorsion (TD) model in rats. In the present study, 32 Sprague Dawley female rats were randomly divided into four groups. Groups planned as sham, TD, $80 \mathrm{mg} / \mathrm{kg}$ dose of AMP+TD, and $160 \mathrm{mg} / \mathrm{kg}$ dose of AMP+TD. In the sham group, the abdomen was opened applying an incision and closed again without TD model. In TD group, 3 hours of torsion followed 3 hours of detorsion were made. In the 80 and $160 \mathrm{mg} / \mathrm{kg}$ dose groups, respectively, AMP was given orally 80 and $160 \mathrm{mg} / \mathrm{kg}$ doses before detorsion and TD was performed as defined in TD group. At the end of detorsion period, rats were sacrificed and the ovarian and lung tissues were quickly removed. All results were analyzed using statistically appropriate tests. Malondialdehyde (MDA) level, myeloperoxidase (MPO) activity, tumor necrosis faktor- $\alpha$ (TNF- $\alpha$ ), interleukin-1beta (IL-1 $\beta$ ), total oxidant status (TOS) and oxidative stress index (OSI) values increased significantly in TD group when compared to sham group $(p \leq 0.05)$. However, superoxide dismutase (SOD) enzyme activity and total antioxidant status (TAS) values decreased in ovarian and lung tissues of TD group. Conversely, SOD enzyme activity increased, while TOS and OSI values, MPO activity and TNF- $\alpha$, IL-1 $\beta$, MDA levels decreased significantly due to administration of AMP in 80 and $160 \mathrm{mg} / \mathrm{kg}$ dose groups ( $\leq 0.05)$. As a conclusion, in this study, it was demonstrated that 80 and $160 \mathrm{mg} / \mathrm{kg}$ doses of AMP administrations protected against oxidative damage of the ovarian and lung tissues that generated by experimental TD in rats.
\end{abstract}

Keywords: Ampelopsin, Torsion/Detorsion, Ovary, Lung, Rat.

https://doi.org/10.36899/JAPS.2020.6.0156

Published online August 03,2020

\section{INTRODUCTION}

Ovarian torsion, mostly seen in reproductive ages (particularly in first three decades), is a common gynecological emergency (Oelsner et al. 2003). Several health conditions such as adnexal venous congestion and long mesovarium may end up with ovarian torsion and soon after obstruction in ovarian vessels. This is a lifethreatening situation results in tissue blood flow reduction and permanent damage in tissues (Oelsner and Shashar 2006). Early diagnosis and treatment are important to salvage the viability of the ovary and to maintain fertility (Huchon and Fauconnier 2010; Smolinski et al. 2015; Rey-Bellet Gasser et al. 2016). Cell damage due to reperfusion depends on various factors but mostly oxygen-derived free radicals, which are quickly produced in tissue by virtue of reperfusion (Nakagiri et al. 2010). Unbalance between antioxidants and free oxygen radicals is called as oxidative stress (Frederiks and Bosch 1995). Increased oxidative stress causes tissue damage which can be end up with necrosis or apoptosis (Kroemer et al. 2007; Broughton et al. 2009). Reactive oxygen species (ROS) may lead to oxidative damage directly on lipids, DNA and proteins (Casini et al. 1997; Ito et al. 2003). Intracellular enzymes like glutathione peroxidase (GSH-Px), superoxide dismutase (SOD) and catalase (CAT) protect cells from ROS (Kurt et al. 2015; Topdağı et al. 2020). It has previously been proposed that the use of antioxidant pharmacological agents before or during reperfusion might protect against ovarian ischemia reperfusion (I/R) injury (Kohen and Nyska 2002; Park et al. 2013; Sengul et al. 2013). I/R injury has a complex pathophysiological mechanism. For example; ROS lead to injury, leukocytes perform adhesive infiltration, inflammatory mediators are released, energy metabolism is corrupted, etc.(Bertoni et

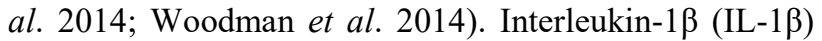
and tumor necrosis factor- $\alpha$ (TNF- $\alpha$ ) are examples for proinflammatory cytokines which appear in the early stages of inflammation, lead to neutrophil oxidative burst and free radical release (Dinarello 2000; Eltzschig and Collard 2004). I/R directly causes to damage in the primary organ. However, it has been reported by some researchers that $\mathrm{I} / \mathrm{R}$ leads to the remote organ damage initiating a series of inflammatory and oxidative reactions 
in the secondary organs and tissues (Sahna et al. 200; Oguz et al. 2015).

Ampelopsin (2R,3R)-3,5,7-trihydroxy-2- (3,4,5trihydroxyphenyl) -2,3-dihydrochromen-4-, AMP, Figure 1) is a bioactive component, also goes by the name of dihydromyricetin, and is among the most common flavonoids. Ampelopsis grossedentata (Hand-Mazz), commonly used in traditional Chinese medicine, is isolated from the leaves and roots of WT Wang which is specifically preferred to make an infusion called Rattan tea (Murakami et al. 2004; Kou and Chen 2012; Ye et al. 2017). AMP has a great variety of pharmacological activities involving anti-hypertensive, antifungal, antiinflammatory, anticarcinogenic, anti-alzheimer and anticholinesterase abilities (Zhang et al. 2012; Zhou et al. 2014; Dung et al. 2015; Ye et al. 2017). AMP has strong antioxidant and anti-microbial activities and also hepatoprotective effect in different experimental protocols (Murakami et al. 2004).

We aimed to evaluate the possible beneficial effects of AMP, which has various biological properties such as antioxidant, anti-inflamatory on ovary as a primer organ and lung as a remote organ in order to alleviate the oxidative damage in the adnexial TD model.Also, as a result of our detailed literature reviews, we could not find any study about treatment or prophylactic effectiveness of AMP in TD model which is applied on ovarian tissue. In this respect, this is a valuable and orginal study that will contribute to the scientific literature.

\section{MATERIALS AND METHODS}

Experimental phase of this research was performed at Atatürk University Experimental Animal Research and Application Center and experiment animals were supplied by the same place.Animals were kept into standard cages in laboratory environment provided with humidity, temperature and light/dark cycle control. Animals had access to food and water ad libitum.Animals were fasted before the experiment for 12 hours to prevent anesthesia complications. This research was initiated with approval of Atatürk University Experimental Animals Local Ethics Committee (30.06.2017/68).

Experimental Groups and Torsion/Detorsion Model: Sprague Dawley type female rats $(n=32)$ were weighed $(260 \pm 10 \mathrm{~g})$ and randomized into 4 groups. In sham group, the abdominal area was shaved, cleaned and opened with an incision under the anesthesia (ketamine/xylazine 60/10 $\mathrm{mg} / \mathrm{kg}$ i.p) and then closed again without TD model or any medication application. Anesthesia method and dosage were selected based on the previous studies (Ekinci Akdemir and Tanyeli, 2019; Topdağı et al. 2019). In TD group, immediately anesthesiawas given, after the subjects were prepared in the dorsal horizontal position, the incision field was washed using by povidone iodine and laparotomy incision was opened as 1-2 cm. Bilateral arteria, veins of ovary, fallopian tube and ovaries were rotated in clockwise 360 degrees and held with atraumatic microvascular clamp for 3 hours. Later, allowing blood circulation for 3 hours by opening the clamps in the detorsion period. Incision was closed with silk 3/0 suture. In this study, the ischemia-reperfusion (3 hours; 3 hours) time was used in the experimental ovarian TD model was preferred based on previous studies(Sahin Ersoy et al. 2016). In 80 and $160 \mathrm{mg} / \mathrm{kg}$ doses AMP+TD groups, AMP was administered to rats orally at the doses of 80 and $160 \mathrm{mg} / \mathrm{kg}$ for 1 week before TD process.AMP(molecular formula; $\mathrm{C}_{15} \mathrm{H}_{12} \mathrm{O}_{8}$, purity $\geq$ 98\%) was purchased from Chem Faces. Ketamine and xylazine hydrochloride were bought from Rompun ${ }^{\circledR}$, Bayer, Istanbul and Ketalar ${ }^{\circledR}$, Pfizer, Istanbul, Turkey. AMP doseswere selected as a reference dose used the previous researches (Yeet al. 2017). Later, as described in TD group, the TD model was established. Following the experiment, all subjects were sacrificed by applying high-dose anesthesia, abdominal and thoracic areas were opened and then lung and ovarian tissues were removed. Finally, when the experiment is over, ovarian and lung tissues were washed and kept frozen at $-80{ }^{\circ} \mathrm{Cuntil}$ the biochemical analysis.

Biochemical Measurements: Ovarian and lung tissues were processed for malondialdehyde (MDA) assay to determine lipid peroxidation status according to methods of Ohkawa et al(1979). The results were given as $\mu \mathrm{mol} / \mathrm{g}$ tissue. It was measured using SOD activity determination protocol defined by Sun et al(1988). The results of tissue samples were presented in $\mathrm{U} / \mathrm{mg}$ protein. We also quantified ovarian and lung injuries by measuring tissue myeloperoxidase (MPO) activity, the activity of infiltrated neutrophils, using a protocol developed by Bradley et al(1982). The results of MPO activity in tissue samples were given in $\mathrm{U} / \mathrm{g}$ protein. The total antioxidant status (TAS) value was calculated with the commercially available kit (Rel Assay Diagnostics). Total oxidant status (TOS) measurement was made with commercially available kit (Rel Assay Diagnostics). TAS and TOS results were presented as $\mathrm{nmol} / \mathrm{L}$. TOS to TAS ratio was admitted as the Oxidative Stress Index (OSI). OSI value was detected as follows: OSI $=\left[\left(\mathrm{TOS}, \mu \mathrm{mol} \mathrm{H}_{2} \mathrm{O}_{2}\right.\right.$ equivalent/L)/(TAS, mmol Trolox equivalent/L) $\times 10]$. OSI may demonstrate the state of oxidative status more precisely compared to TOS value. IL- $1 \beta$ and TNF- $\alpha$ levels were determined with the commercially available kits(Elabscience, Wuhan, China). The results of IL-1 $\beta$ and TNF- $\alpha$ were presented as $\mathrm{pg} / \mathrm{mg}$ protein.

Statistical Analysis: For all the results obtained in this study, statistical analysis was done using SPSS package program. For this purpose data of one-way analysis of variance (ANOVA) and Tukey from post hoc tests were applied in determining the relationship among groups. 
Descriptive statisticsweregiven as the mean \pm SEM. The results were evaluated statistically meaningful at $\mathrm{p} \leq 0.05$ level.

\section{RESULTS AND DISCUSSION}

In this research it was applied AMP against ovarian and lung tissue injuries induced by experimental ovarian TD model, it was found that MPO activity, MDA, IL- $1 \beta$ and TNF- $\alpha$ levels, TOS and OSI values were significantly higher in TD group compared to sham group, but these results significantly reduced due to 80 and $160 \mathrm{mg} / \mathrm{kg}$ doses of AMP application in ovarian and lung tissues (see Table 1-2, Figure 2,3,4, $\mathrm{p} \leq 0.05$ ).

SOD activity and TAS value are the antioxidant parameter levels and they were found to be lower in TD group compared to sham and other groups. The results of SOD activity and TAS value importantly increased via 80 and $160 \mathrm{mg} / \mathrm{kg}$ doses of AMP administration in ovarian and lung tissues (see Table 1-2, $\mathrm{p} \leq 0.05$ ).

Adnexal rotation directly leads to torsion. Rotation degree is effective on prognosis. Ischemia occurs due to ovarian torsion and in case of late treatment, necrosis occurs. There has been found no clear information about ovarian injury pathophysiology (Sagsoz et al. 2002). MDA and ROS levels increase due to I/R injury. Neutrophil adhesion and ROS secretion are observed during I/R injury (Kurose and Granger 1994). Lipid peroxidation is a result of ROS generation and it leads to impairment in cell membrane permeability, disruption in cellular integrity and eventually cell injury (Refaie and El-Hussieny 2017). Lipid peroxidation produces MDA and fatty acids (with three or more double bonds) take charge in this process. MDA leads to cross-linking of membrane components and then enzyme activity and ion permeability change by affecting the ion exchange through the cell membranes (Niki et al. 2005; Ximenes et al. 2005). Leukocytes accumulate and ROS increase in detorsion phase (Bozkurt et al. 2012). Aerobic metabolism involves ROS as an active component and it is purified by antioxidant enzymes like SOD and CAT (Gough and Cotter 2011). GSH and SOD are examples for natural free radical scavengers which take role on protection of tissues and organs against injury induced by ROS. In case of antioxidant and free radical scavenger depletion, ROS-induced injury and lipid peroxidation increase(Li et al. 2015). SOD is an important molecule in endogenous defence system which plays role against free radicals (Senbel et al. 2014). TOS and TAS are used in $\mathrm{I} / \mathrm{R}$ injury evaluation (Yaziciet al. 2014). TOS shows negative correlation with TAS (Erel 2004; Erel 2005). IL$1 \beta$ and TNF-aare examples for proinflammatory cytokines which appear in early stages of inflammation, lead to neutrophil oxidative burst and free radical release (Dinarello 2000; Eltzschig and Collard 2004). Several antioxidants demonstrated prevention against oxidative injury and inflammation in ovarian tissues exposed to I/R injury (Prieto-Moure et al. 2016). AMPwas preferred in this model which has a strong antioxidant and antiinflammatory effects for this purpose.

Many AMP-related studies are available in the literature supporting the results of present study. In this study, reduction of levels of oxidant and inflammatory parameters in ovarian TDinjury model in rats by AMP, suggesting that AMP decreased TD-induced injuries of ovarian and lung tissues.Intracellular ROS formation plays a critical role in modulating cell death, cell survivaland the production of massive amounts of ROS is known to be an important molecular mechanism that contributes to cell death by triggering cellular toxicity. Also, in addition, ROS is associated with a wide range and variety of different clinical conditions by activation of different signal transduction or transcriptional pathways (Simon et al. 2000; Fleury et al. 2002). In a study evaluating the therapeutic efficacy of AMP, it was reported to reduce the expression of nitric oxide and proinflammatory cytokines like TNF- $\alpha$, IL- 6 and IL- $1 \beta$ from lipopolysaccharide-induced by decreasing ROS level or by supporting downregulation (Qi et al. 2012).In another experimental study evaluating the medicable effect of AMP on acute phase response induced by lipopolysaccharide, it was reported that AMP treatment increased SOD, glutathione peroxidase, glutathione reductase activities and total glutathione levels by reducing oxidative stress and inflammation in liver tissue (Hou et al. 2017). Furthermore, it has been detected that AMP has influence to preclude the oxidative stress intracellular that may have been formed via ROS produced by macrophages due to the effect of Dgalactosamine (Murakami et al. 2004). In addition, in another study, there has been valuable scientific knowledge that ROS-mediated activation of $\mathrm{PI} 3 \mathrm{~K} / \mathrm{Akt} / \mathrm{NF}-\kappa \mathrm{B}$ signaling pathways were suppressed due to AMP administration and AMP alleviated endotoxic inflammation (Qi et al. 2012). In parallel with these studies, in present study, antioxidant and antiinflammatory properties of AMP have been shown in ovarian and lung tissues in TD model. In TD group, TAS level and SOD activity decreased while MPO activity, IL-1 $\beta$, MDA, TNF- $\alpha$ levels, OSI, TOS values were increased and AMP treatment reversed these levels.

We assessed oxidative stress in the ovarian and lung tissues to search the possible mechanisms of the protective effect of AMP against TD-induced ovarian and lung tissues injuries. It was observed that oxidative stress decreased with AMP. To make effective changes in the clinical management of TD, the pathogenesis of TDinduced organ damage should be better understood for the development of therapeutic strategies. Clearly observed in $\mathrm{I} / \mathrm{R}$ studies that inflammation, oxidative stress suppression can provide significant contributions to the treatment of I/R. In the current study, inflammation, 
oxidative stress pathways were suppressed by AMP and this promise hope in the treatment of TD.

Table 1. Mean, minimum, maximum and standart error mean of Total Antioxidant Status (TAS), Total Oxidant Status (TOS) and Oxidative Stress Index (OSI) values of ovarian and lung tissues of all groups.

\begin{tabular}{|c|c|c|c|c|c|c|c|}
\hline \multicolumn{5}{|c|}{ Ovarian Tissue } & \multicolumn{3}{|c|}{ Lung Tissue } \\
\hline & & $\begin{array}{c}\text { TAS } \\
(\mathrm{mmol} / \mathrm{L})\end{array}$ & $\begin{array}{c}\text { TOS } \\
(\mu \mathrm{mol} / \mathrm{L})\end{array}$ & $\begin{array}{c}\text { OSI } \\
\text { (TAS/TOS) }\end{array}$ & $\begin{array}{c}\text { TAS } \\
(\mathrm{mmol} / \mathrm{L})\end{array}$ & $\begin{array}{c}\text { TOS } \\
(\mu \mathrm{mol} / \mathrm{L})\end{array}$ & $\begin{array}{c}\text { OSI } \\
\text { (TAS/TOS) }\end{array}$ \\
\hline \multirow[t]{4}{*}{ Sham } & Mean & $0.67^{\mathrm{a}}$ & $5.36^{\mathrm{a}}$ & $0.81^{\mathrm{a}}$ & $1.00^{\mathrm{a}}$ & $6.65^{\mathrm{a}}$ & $0.66^{\mathrm{a}}$ \\
\hline & Minimum & 0.49 & 4.82 & 0.58 & 0.87 & 5.69 & 0.56 \\
\hline & Maximum & 0.83 & 5.88 & 1.10 & 1.27 & 7.53 & 0.86 \\
\hline & Std. Error of Mean & 0.03 & 0.13 & 0.05 & 0.04 & 0.22 & 0.03 \\
\hline \multirow[t]{4}{*}{ TD } & Mean & $0.36^{\mathrm{a}, \mathrm{b}, \mathrm{c}}$ & 8.51 & 2.35 & $0.60^{\mathrm{a}, \mathrm{b}, \mathrm{c}}$ & $8.91^{\mathrm{a}, \mathrm{b}, \mathrm{c}}$ & $1.47^{\mathrm{a}, \mathrm{b}, \mathrm{c}}$ \\
\hline & Minimum & 0.30 & 7.12 & 1.88 & 0.52 & 7.18 & 1,25 \\
\hline & Maximum & 0.43 & 9.44 & 3.03 & 0.71 & 10.22 & 1.88 \\
\hline & Std. Error of Mean & 0.01 & 0.27591 & 0.15 & 0.02 & 0.33 & 0.06 \\
\hline $80 \mathrm{mg} / \mathrm{kg}$ & Mean & $0.57^{b}$ & $6.06^{\mathrm{b}}$ & $1.06^{\mathrm{b}}$ & $0.92^{b}$ & $7.27^{b}$ & $0.7954^{\mathrm{b}}$ \\
\hline doses of & Minimum & 0.48 & 5.23 & 0.89 & 0.79 & 6.01 & 0.62 \\
\hline \multirow[t]{2}{*}{$\mathrm{AMP}+\mathrm{TD}$} & Maximum & 0.67 & 7.07 & 1.33 & 1.08 & 8.33 & 0.98 \\
\hline & Std. Error of Mean & 0.02 & 0.20 & 0.06 & 0.03 & 0.29 & 0.04 \\
\hline $160 \mathrm{mg} / \mathrm{kg}$ & Mean & $0.63^{c}$ & $5.57^{\mathrm{c}}$ & $0.88^{c}$ & $1.00^{\mathrm{c}}$ & $7.06^{\mathrm{c}}$ & $0.72^{\mathrm{c}}$ \\
\hline doses of & Minimum & 0.54 & 5.01 & 0.77 & 0.83 & 6.22 & 0.53 \\
\hline \multirow[t]{2}{*}{$\mathrm{AMP}+\mathrm{TD}$} & Maximum & 0.70 & 6.56 & 1.08 & 1,17 & 8.37 & 1.00 \\
\hline & Std. Error of Mean & 0.02 & 0.20 & 0.04 & 0.04 & 0.28 & 0.05 \\
\hline
\end{tabular}

a,b,c:Among the groups that has the same letters are statistically significant at the $\mathrm{p} \leq 0.05$ level.

Table 2. Mean, minimum, maximum and standart error mean of Superoxide Dismutase (SOD) activity and Malondialdehyde (MDA) level of ovarian and lung tissues of all groups.

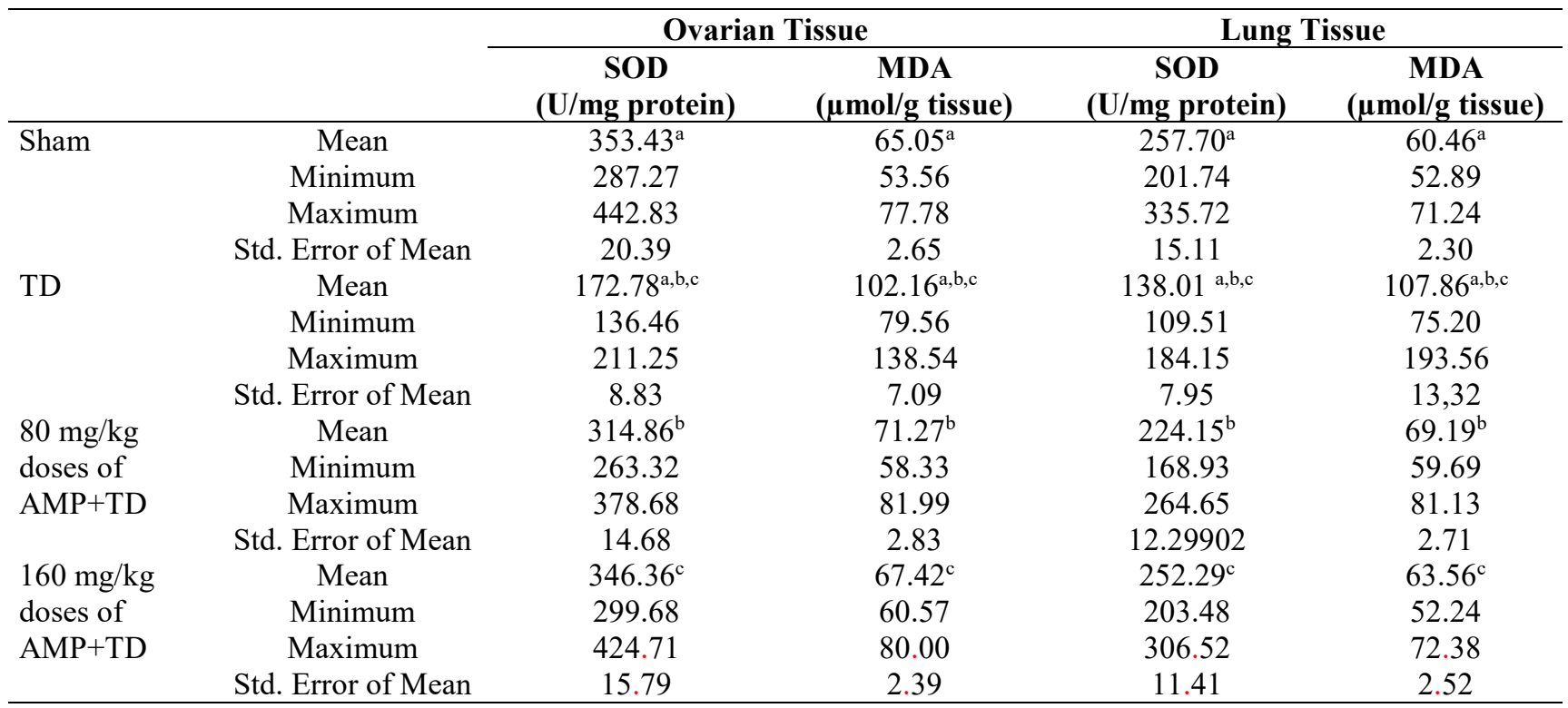

a,b,c: Among the groups that has the same letters are statistically significant at the $\mathrm{p} \leq 0.05$ level 


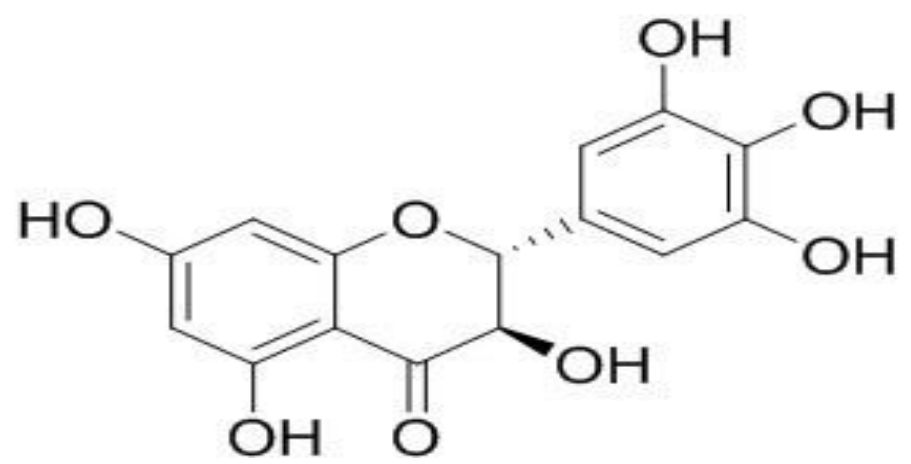

Figure 1. Chemical structure of ampelopsin (Kou, Li et al. 2015).

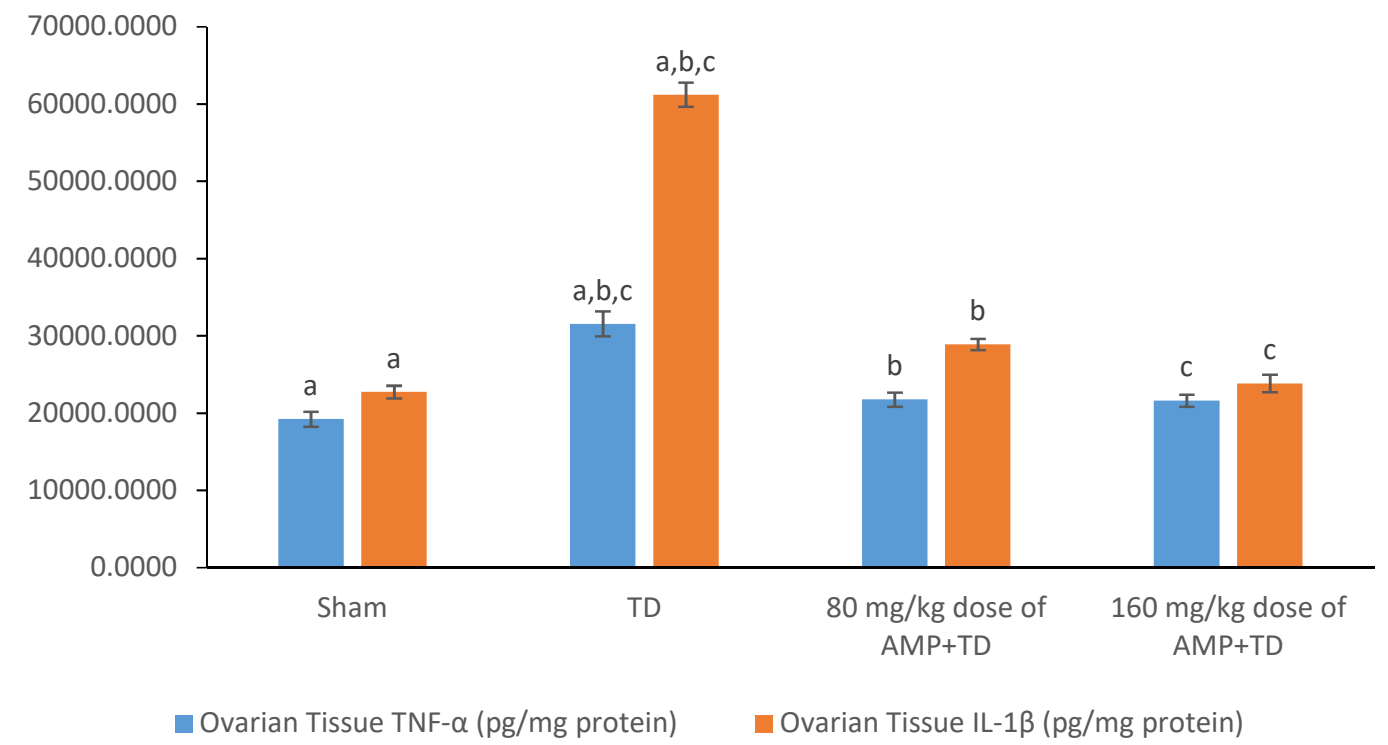

Figure 2. Tumor necrosis factor-alpha (TNF- $\alpha$ ) and Interleukin 1beta (IL-1ß) level of ovarian tissue of all groups. $a, b, c: A m o n g$ the groups that has the same letters are statistically significant at the $\mathbf{p} \leq \mathbf{0 . 0 5}$ level.

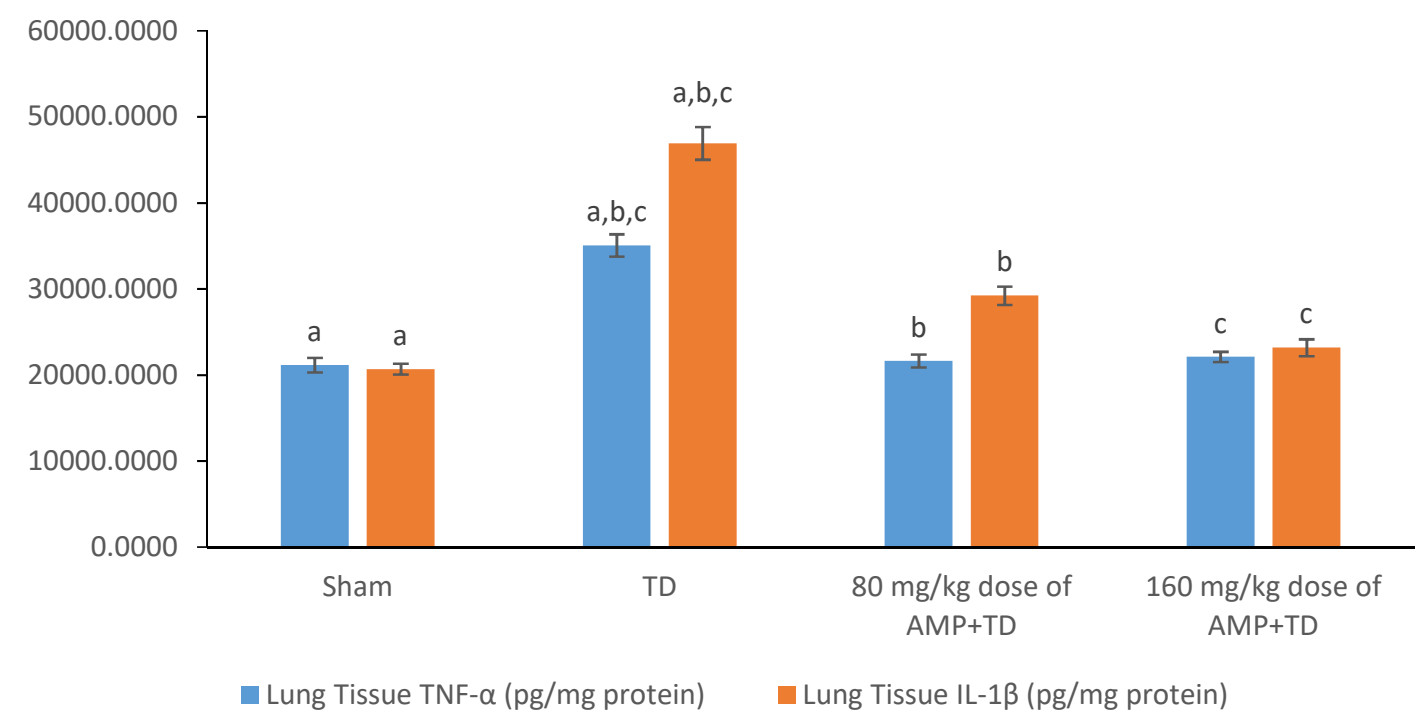

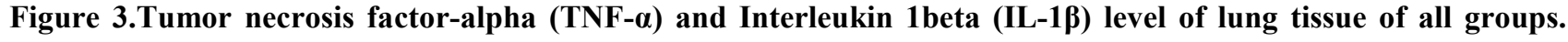
a,b,c: Among the groups that has the same letters are statistically significant at the $\mathbf{p} \leq \mathbf{0 . 0 5}$ level 


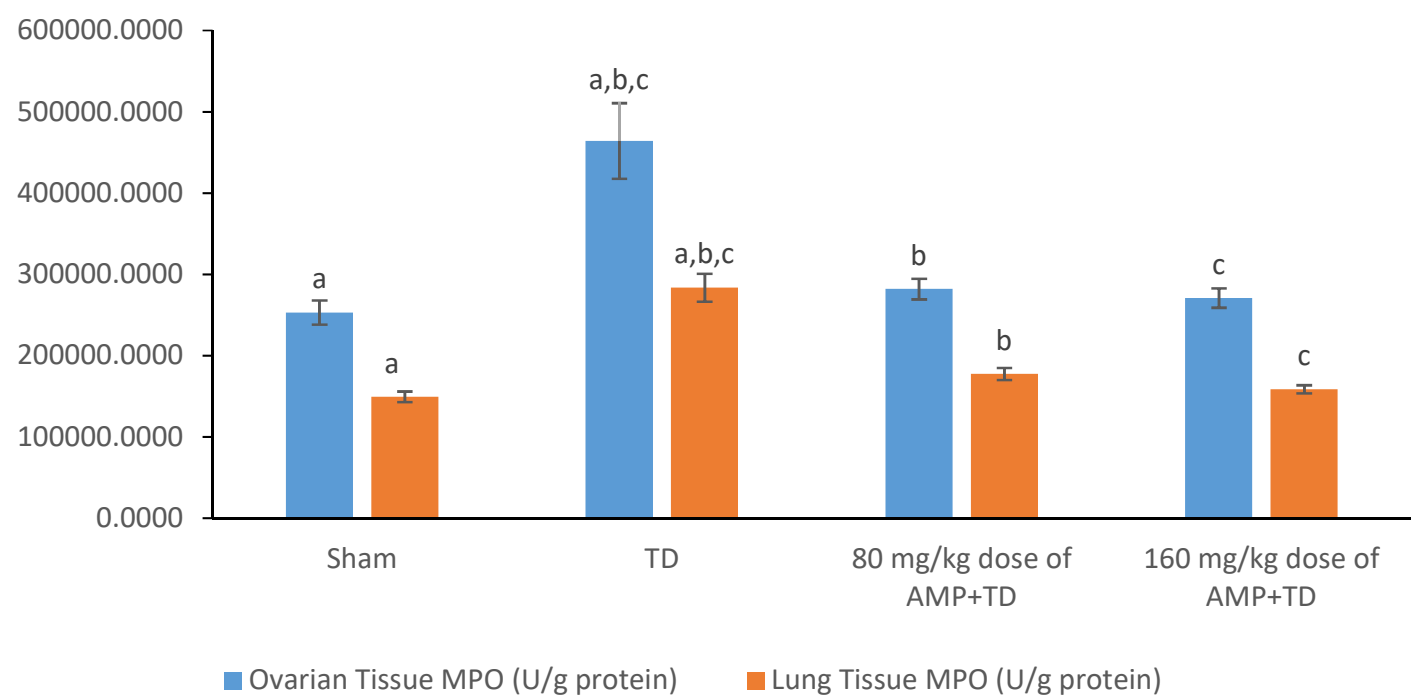

Figure 4.Myeloperoxidase (MPO) activities of ovarian and lung tissues of all groups. a,b,c: Among the groups that has the same letters are statistically significant at the $\mathbf{p} \leq \mathbf{0 . 0 5}$ level.

Conclusions:After all the data were evaluated, it is possible to say that treatment with AMP reduces ovarian and lung tissue damage in experimental animals exposed to TD model. Moreover, further researches are necessary for explain the other protective mechanismsin TDinduced ovarian and lung injuries.

Conflict of interest statement: The authors declare that there are no conflicts of interest.

Financial Support: None

\section{REFERENCES}

Bertoni, S., V. Arcaro, V. Vivo, A. Rapalli, M. Tognolini, A. M. Cantoni, F. Saccani, L. Flammini, G. Domenichini, V. Ballabeni and E. Barocelli (2014). Suppression of inflammatory events associated to intestinal ischemia-reperfusion by 5 -HT1A blockade in mice. Pharmacol. Res. 81: $17-25$.

Bozkurt, S., D. C. Arikan, E. B. Kurutas, H. Sayar, M. Okumus, A. Coskun and V. Bakan (2012). Selenium has a protective effect on ischemia/reperfusion injury in a rat ovary model: biochemical and histopathologic evaluation. J. Pediatr. Surg. 47(9): 1735-1741.

Bradley, P. P., D. A. Priebat, R. D. Christensen and G. Rothstein (1982). Measurement of cutaneous inflammation: estimation of neutrophil content with an enzyme marker. J. Invest. Dermatol. 78(3): 206-209.

Broughton, B. R., D. C. Reutens and C. G. Sobey (2009).Apoptotic mechanisms after cerebral ischemia. Stroke 40(5): e331-339.
Casini, A., E. Ceni, R. Salzano, P. Biondi, M. Parola, A. Galli, M. Foschi, A. Caligiuri, M. Pinzani and C. Surrenti (1997). Neutrophil-derived superoxide anion induces lipid peroxidation and stimulates collagen synthesis in human hepatic stellate cells: role of nitric oxide. Hepatol. 25(2): 361-367.

Dinarello, C. A. (2000). Proinflammatory cytokines. Chest 118(2): 503-508.

Dung, H. V., T. D. Cuong, N. M. Chinh, D. Quyen, J. A. Kim, J. S. Byeon, M. H. Woo, J. S. Choi and B. S. Min (2015). Compounds from the aerial parts of Piper bavinum and their anticholinesterase activity. Arch. Pharm. Res. 38(5): 677-682.

Eltzschig, H. K. and C. D. Collard (2004). Vascular ischaemia and reperfusion injury. Br. Med. Bull. 70: 71-86.

Ekinci Akdemir F. N. and A. Tanyeli, (2019). The Antioxidant Effect of Fraxin against Acute Organ Damage in Polymicrobial Sepsis Model induced by Cecal Ligation and Puncture, Turkish J. Sci. (TJOS) 4. 22-29.

Erel, O. (2004). A novel automated method to measure total antioxidant response against potent free radical reactions. Clin. Biochem. 37(2): 112119.

Erel, O. (2005). A new automated colorimetric method for measuring total oxidant status. Clin. Biochem. 38(12): 1103-1111.

Fleury, C., B. Mignotte and J. L. Vayssiere (2002). Mitochondrial reactive oxygen species in cell death signaling. Biochimie. 84(2-3): 131-141. 
Frederiks, W. M. and K. S. Bosch (1995). The role of xanthine oxidase in ischemia/reperfusion damage of rat liver. Histol. Histopathol. 10(1): 111-116.

Gough, D. R. and T. G. Cotter (2011). Hydrogen peroxide: a Jekyll and Hyde signalling molecule. Cell Death Dis. 2: 213.

Hou, X., T. Wang, H. Ahmad and Z. Xu (2017). Ameliorative effect of ampelopsin on LPSinduced acute phase response in piglets. J. Func. Food 35: 489-498.

Huchon, C. and A. Fauconnier (2010). Adnexal torsion: a literature review. Eur. J. Obstet. Gynecol. Reprod. Biol. 150(1): 8-12.

Ito, K., H. Ozasa, N. Kojima, M. Miura, T. Iwa, H. Senoo and S. Horikawa (2003). Pharmacological preconditioning protects lung injury induced by intestinal ischemia/reperfusion in rat. Shock 19(5): 462-468.

Kohen, R. and A. Nyska (2002). Oxidation of biological systems: oxidative stress phenomena, antioxidants, redox reactions, and methods for their quantification. Toxicol. Pathol. 30(6): 620-650.

Kou, X. and N. Chen (2012). Pharmacological potential of ampelopsin in Rattan tea.Food Sci Human Well. 1(1): 14-18.

Kou, X., J. Li, J. Bian, Y. Yang, X. Yang, J. Fan, S. Jia and N. Chen (2015). Ampelopsin attenuates 6OHDA-induced neurotoxicity by regulating GSK-3 $\beta$ /NRF2/ARE signalling.J. Func. Foods 19: 765-774.

Kroemer, G., L. Galluzzi and C. Brenner (2007). Mitochondrial membrane permeabilization in cell death. Physiol. Rev. 87(1): 99-163.

Kurose, I. and D. N. Granger (1994). Evidence implicating xanthine oxidase and neutrophils in reperfusion-induced microvascular dysfunction. Ann. N. Y. Acad. Sci. 723: 158179.

Kurt, R. K., A. C. Dogan, M. Dogan, A. Albayrak, S. N. Kurt, F. Eren, A. G. Okyay, A. Karateke, M. Duru, E. Fadillioglu and T. Delibasi (2015). Protective effect of colchicine on ovarian ischemia-reperfusion injury: an experimental study. Reprod. Sci. 22(5): 545-550.

Li, S., H. Y. Tan, N. Wang, Z. J. Zhang, L. Lao, C. W. Wong and Y. Feng (2015). The Role of Oxidative Stress and Antioxidants in Liver Diseases. Int. J. Mol. Sci. 16(11): 2608726124.

Murakami, T., M. Miyakoshi, D. Araho, K. Mizutani, T. Kambara, T. Ikeda, W. H. Chou, M. Inukai, A. Takenaka and K. Igarashi (2004). Hepatoprotective activity of tocha, the stems and leaves of Ampelopsis grossedentata, and ampelopsin.Biofac. 21(1-4): 175-178.

Nakagiri, A., M. Sunamoto, K. Takeuchi and M. Murakami (2010). Evidence for the involvement of NADPH oxidase in ischemia/reperfusion-induced gastric damage via angiotensin II. J. Physiol. Pharmacol. 61(2): 171-179.

Niki, E., Y. Yoshida, Y. Saito and N. Noguchi (2005). Lipid peroxidation: mechanisms, inhibition, and biological effects. Biochem. Biophys. Res. Commun. 338(1): 668-676.

Oelsner, G., S. B. Cohen, D. Soriano, D. Admon, S. Mashiach and H. Carp (2003). Minimal surgery for the twisted ischaemic adnexa can preserve ovarian function. Hum. Reprod. 18(12): 2599-2602.

Oelsner, G. and D. Shashar (2006). Adnexal torsion. Clin. Obstet. Gynecol. 49(3): 459-463.

Oguz, A., M. Kapan, I. Kaplan, U. Alabalik, B. V. Ulger, O. Uslukaya, A. Turkoglu and Y. Polat (2015). The effects of sulforaphane on the liver and remote organ damage in hepatic ischemiareperfusion model formed with pringle maneuver in rats.Int. J. Surg. 18: 163-168.

Ohkawa, H., N. Ohishi and K. Yagi (1979). Assay for Lipid Peroxides in Animal-Tissues by Thiobarbituric Acid Reaction.Anal. Biochem. 95(2): 351-358.

Topdağı Ö., a. Tanyeli, F. N. Ekinci Akdemir, D. Güzel Erdoğan, M. C. Güler, and E. Eraslan, (2019). The Effects of Higenamine on Testicular Damage Injured by Ischemia Reperfusion A Biochemical Study, Turkish J. Sci. 4(2), 9299.

Park, E. S., J. Kim, T. U. Ha, J. S. Choi, K. Soo Hong and J. Rho (2013). TDAG51 deficiency promotes oxidative stress-induced apoptosis through the generation of reactive oxygen species in mouse embryonic fibroblasts. Exp. Mol. Med. 45: 35.

Prieto-Moure, B., J. M. Lloris-Carsi, C. Barrios-Pitarque, L. H. Toledo-Pereyra, J. M. Lajara-Romance, M. Berda-Antoli, J. M. Lloris-Cejalvo and D. Cejalvo-Lapena (2016). Pharmacology of Ischemia-Reperfusion. Translational Research Considerations. J. Invest. Surg. 29(4): 234 249.

Qi, S., Y. Xin, Y. Guo, Y. Diao, X. Kou, L. Luo and Z. Yin (2012). Ampelopsin reduces endotoxic inflammation via repressing ROS-mediated activation of $\mathrm{PI} 3 \mathrm{~K} / \mathrm{Akt} / \mathrm{NF}-\mathrm{kappaB}$ signaling pathways. Int. Immunopharmacol. 12(1): 278287.

Refaie, M. M. M. and M. El-Hussieny (2017). The role of interleukin-1b and its antagonist (diacerein) in 
estradiol benzoate-induced endometrial hyperplasia and atypia in female rats. Fundam. Clin. Pharmacol. 31(4): 438-446.

Rey-Bellet Gasser, C., M. Gehri, J. M. Joseph and J. Y. Pauchard (2016). Is It Ovarian Torsion? A Systematic Literature Review and Evaluation of Prediction Signs. Pediatr. Emerg. Care 32(4): 256-261.

Sagsoz, N., U. Kisa and A. Apan (2002). Ischaemiareperfusion injury of rat ovary and the effects of vitamin C, mannitol and verapamil. Hum. Reprod. 17(11): 2972-2976.

Sahin Ersoy, G., M. Eken, R.Tal, cD. Oztekin,B. Devranoglu, E. Kaygusuz andO. Cevik. (2016). N-acetylcysteine leads to greater ovarian protection than enoxaparin sodium in a rat ovarian torsion model. Reprod Biomed Online. 33: 93-101.

Sahna, E., G. Turk, A. Atessahin, S. Yilmaz and E. Olmez (2007). Remote organ injury induced by myocardial ischemia and reperfusion on reproductive organs, and protective effect of melatonin in male rats. Fertil. Steril. 88(1): 188-192.

Senbel, A. M., L. AbdelMoneim and A. G. Omar (2014). Celecoxib modulates nitric oxide and reactive oxygen species in kidney ischemia/reperfusion injury and rat aorta model of hypoxia/reoxygenation. Vascul. Pharmacol. 62(1): 24-31.

Sengul, O., I. Ferah, B. Polat, Z. Halici, Y. Bayir, M. Yilmaz, N. Kilic and O. N. Keles (2013). Blockade of endothelin receptors with bosentan limits ischaemia/reperfusion-induced injury in rat ovaries.Eur. J. Obstet. Gynecol. Reprod. Biol. 170(2): 458-463.

Simon, H. U., A. Haj-Yehia and F. Levi-Schaffer (2000). Role of reactive oxygen species (ROS) in apoptosis induction.Apoptos. 5(5): 415-418.

Smolinski, S. E., A. Kreychman and T. Catanzano (2015). "Ovarian Torsion: Multimodality Review of Imaging Characteristics. J. Comput. Assist. Tomogr. 39(6): 922-924.
Sun, Y., L. W. Oberley and Y. Li (1988). A Simple Method for Clinical Assay of SuperoxideDismutase. Clin. Chem. 34(3): 497-500.

Topdağı, Ö., A. Tanyeli, F.N. Ekinci Akdemir, E. Eraslan, and M.C. Güler, (2020). Barbaloin Attenuates Oxidative Testicular Injury Induced by Ischemia Reperfusion via Antioxidant and Anti-Inflammatory Effects. Turkish J. Sci. (TJOS) 5(1), 28-33.

Woodman, O. L., R. Long, S. Pons, N. Eychenne, A. Berdeaux and D. Morin (2014). The cardioprotectant 3',4'-dihydroxyflavonol inhibits opening of the mitochondrial permeability transition pore after myocardial ischemia and reperfusion in rats. Pharmacol. Res. 81: 26-33.

Ximenes, V. F., I. M. Paino, O. M. Faria-Oliveira, L. M. Fonseca and I. L. Brunetti (2005). Indole ring oxidation by activated leukocytes prevents the production of hypochlorous acid. Braz. J. Med. Biol. Res. 38(11): 1575-1583.

Yazici, S., S. Demirtas, O. Guclu, O. Karahan, C. Yavuz, A. Caliskan and B. Mavitas (2014). Using oxidant and antioxidant levels to predict the duration of both acute peripheral and mesenteric ischemia. Perfusion 29(5): 450455.

Ye, X. L., L. Q. Lu, W. Li, Q. Lou, H. G. Guo and Q. J. Shi (2017). Oral administration of ampelopsin protects against acute brain injury in rats following focal cerebral ischemia. Exp. Ther. Med. 13(5): 1725-1734.

Zhang, B., S. Dong, X. Cen, X. Wang, X. Liu, H. Zhang, $X$. Zhao and Y. Wu (2012). Ampelopsin sodium exhibits antitumor effects against bladder carcinoma in orthotopic xenograft models. Anticancer Drug. 23(6): 590-596.

Zhou, Y., F. Shu, X. Liang, H. Chang, L. Shi, X. Peng, J. Zhu and M. Mi (2014). Ampelopsin induces cell growth inhibition and apoptosis in breast cancer cells through ROS generation and endoplasmic reticulum stress pathway. PLoS One .9(2): 89021. 